DOI: 10.4312/an.49.1-2.29-51

\title{
Topicality and Conceptual Blending in Shakespeare's Henriad - The Case of the Earl of Essex
}

\section{Elke Mettinger}

\section{Abstract}

The goal of the following article is to analyse topical allusions to the Earl of Essex in Shakespeare's Henriad in terms of conceptual blending theory in order to shed light on the reception of these plays in the early modern public theatre and to find clues to Shakespeare's intentions.

Key words: Shakespeare, Henriad, Earl of Essex, conceptual blending, topicality 
This essay sets out to identify topical allusions to the Earl of Essex and his political career in the 1590s up to his death in 1601 in Shakespeare's Henriad, his second historical tetralogy, and to analyse them in terms of conceptual blending theory. The purpose will be to find out how early audiences possibly received performances of Shakespeare's histories at the (Globe) theatre and how critics today can perhaps, at least partly, infer Shakespeare's intentions.

Charles Whitney defines topicality "as the pressure of the events, issues, and political agendas of the day on the responses of different sets of playgoers" ("Festivity" 412). Nicholas Moschovakis understands topicality "as a kind of meaning that presumes an interpreter's familiarity with particular, publicly reported events or controversies, to which an imaginative work alludes more or less implicitly" (127). Pandit and Hogan consider topical allusions to work like conceptual blends in the minds of authors and their audiences. "In allusive blends [...] topical references are left implicit, but they nonetheless trigger memories and associations. These memories and associations contribute to our mental modelling of characters, scenes, and events" (10).

In this sense the following paper assumes that Shakespeare intended his Henriad to trigger his audience's access to specific memories of topical and political events shaped by the Earl of Essex, and encourage them to re-evaluate these critically.

Robert Devereux, $2^{\text {nd }}$ Earl of Essex, was Elizabeth I's last favourite and her junior by more than 30 years. Paul Hammer challenges the traditional image of Essex as an incompetent playboy and reveals him as an intellectual aristocrat with a passionate commitment to martial affairs. Essex sought to make himself the leader of his generation by excelling through his young age, virtue, chivalric ethos, military skills, energy and self-sacrifice, zeal, and ambition. His rivalry with the Burghley and Cecil factions and the Queen's increasing ungratefulness and non-receptiveness to his opinions made him more rash and radical (400-403). Janet Dickinson shares Hammer's rehabilitated version of Essex, but still considers him psychologically unstable, reckless and excessive. In accordance with his status as a patron, Essex was at the centre of military-minded aristocrats including Southampton, Charles and Christopher Blount, Danvers, Meyrick and Pérez, Rutland and Bedford (2, 79, 101-102).

After brilliant military achievements against Spain, for instance at Cadiz, he was appointed Lord Lieutenant of Ireland in 1599 to put down the Irish rebellion led by the Earl of Tyrone. He could not accept a lesser man for the task, but knew his enemies would again profit from his absence at court (Shapiro 65). His unsuccessful campaign together with his precipitate, unauthorised return from Ireland worsened his by then strained relationship with the Queen. After his arrest he and his circle rose to an armed rebellion in the streets of London, which failed. 
Recent historians like Dickinson judge his rebellion - as Essex did himself - not as subversion, but as only designed to gain a personal audience with the Queen to restore his favour and free her from false advisors. Dickinson stresses that Essex's aim was neither to overthrow the Queen nor to ensure the succession for himself. Gajda explores the nature of James VI's implications in Essex's rising and the succession debate. Knowing Essex's popularity, the authorities swiftly proclaimed him and his fellow rebels traitors, and Essex ended his life on the scaffold (Dickinson 45-61, 125).

Essex and his difficult relationship with the Queen did not go unnoticed in early modern London and can thus work as the perfect topical foil for a new look at Shakespeare's Henriad - quite in line with Amy Cook who appreciates conceptual blending theory (CBT) as offering "us a methodology to unpack meaning again and again, to find new connections in new times or new plays" ("Interplay" 586). Shakespeare's histories seem particularly apt for CBT: dramatic performances are blends where actors and characters are linked through real and represented worlds; an additional space of historical reality (Fauconnier and Turner 267) comes into play when historical kings like Richard II, Henry IV or Henry V are represented on stage. And we are dealing with yet another mental space when contemporary events around Essex are alluded to. In other words, a whole network of four input spaces creates a blend of past and present, of fictional, theatrical, historical, and contemporary realities. In this network, for instance, the fictional Bullingbrook of Shakespeare's play, the actor representing him in the performance on stage, the historical Bullingbrook and the contemporary Earl of Essex are blended. The four input spaces are history, play, performance with a focus on the actor (representing Bullingbrook), and performance with a focus on the spectator (associating the character with Essex). Matching produces counterpart connections between the input spaces, like e.g. a dead king vs. a living actor. The blend works by selective projection, as not all elements and relations from the input spaces are fused in the blend. The emergent structure of the blend is generated through composition of projection from the input spaces, through completion (that is silently added to or recruited from background meaning), and through elaboration, i.e. the actual running of the blend (Fauconnier and Turner 40-46).

While watching a performance "we are simultaneously aware of the actor moving and talking on a stage in front of an audience, and of the corresponding character moving and talking within the represented story world" (Fauconnier and Turner 266). McConachie applies this to an understanding of actor / character as "a blend of real people and fictional figures whom audiences readily credit with real intentions and emotions when they live in the blend while watching a play" (48). The situation in the theatre thus houses several cognitive levels or mental spaces existing side by side. Apart from the actor / character blend the historical 
reigns of the $14^{\text {th }} / 15^{\text {th }}$ century kings are to be taken into account, inviting comparison with the fictional world of Shakespeare's plays at the time of Elizabeth I, under whose reign they are written and staged, which - in turn - invites comparison with contemporary politics.

The doubleness of theatricality and the performance situation depend on the spectators' ability in conceptual blending (Fauconnier and Turner 266-267). At the interface of history, fiction and politics, different models of memory are at work in diverse spectators. There may be moments when Richard's or Henry's court and Shakespeare's theatre merge, just as there may be occasions when Shakespeare's theatre and the Elizabethan battlefield become one.

What follows is a look at topical passages in Shakespeare's Richard II, 1 Henry $I V$ and Henry $V$. Quite in line with Amy Cook (Neuroplay 19), the aim is to show how CBT informs contemporary spectators' and our own understanding of performances of Shakespeare's Henriad, to see through the network and the emergent structure of the blend, to uncover "connections not immediately apparent" (Cook, Neuroplay 91), but nevertheless essentially relevant. ${ }^{1}$

\section{RICHARD II}

In history plays the audience's historical knowledge can be used for dramatic purposes, as Lukas Lammers (146-154) has convincingly shown through the example of Richard II. Shakespeare can exploit the audience's historical knowledge and create dramatic irony, e.g. when Richard calls Bullingbrook his "kingdom's heir" (1.1.116). Shakespeare provides the audience with "a third perspective" (Rackin 262), some kind of "extra role" (263) or what we could term 'additional blend', following Fauconnier and Turner. For much of the play the audience becomes complicit, even in the crimes committed. In the first acts, the spectators build up antipathy to Richard, the luxuriant, effeminate king. Only when Richard becomes a traitor can the audience finally desire his deposition. In the second part, Shakespeare builds our sympathy for Richard. His cognitive strategy works to transgress the boundary between stage and audience (Rackin 266-281).

Oatley, a leading cognitive scientist of emotion, sees Shakespeare's plays as world-building models, and discusses "these models as simulations that run on [our] minds" (15). Cook applies cognitive science to performance studies employing CBT and using neuroscience (mirror neurons) to shed light on the identification process for actors and audiences. A "performance that activates imitation in an audience is likely to be (almost literally) moving" ("Interplay" 591), for it

1 Some aspects concerning conceptual blending and the analysis of Richard II are based on Mettinger 93-98. 
helps develop empathy. And the "literary version of empathy" (Oatley 29) is identification. According to the theory of mind, simulation is the basic psychological mechanism that - via mirror neurons - deploys empathy. Empathising leads to emotional involvement, and emotions are central to the construction of meaning (McConachie and Hart 5). So the way Shakespeare directs audience empathy and sympathy is very revealing: we have sympathy with Richard despite his faults; and we do not condemn Bullingbrook despite his usurpation. The audience seems to be in the position of making or unmaking kings, desiring their rise or fall or debating principles like providentialism or the legitimacy of power.

Besides, Richard II embodies instances of topical allusion. The space of performance and the space of the contemporary world are blended, creating a new space in which Richard is associated with Elizabeth and Bullingbrook with Essex. This is, to a great extent, due to Shakespeare's use of the cognitive concept of 'popularity' (not to be found in Holinshed or other sources) to construct the character of Bullingbrook, who founds his usurpation on his popularity with the people. 'Popularity' is a salient term that triggers mental processes in the audience of the late 1590s, who strongly associates it with the Earl of Essex and his cultivation of popular favour for political ends. The theatre invites critical judgement from a largely nonelite audience (Doty 189-192), who thus gains what Charles Whitney in his Early Responses to Renaissance Drama calls 'vicarious experience' from which they can profit in their real political world. Richard criticises Bullingbrook's wooing of the common people on leaving London:

Our self and Bushy, Bagot here and Green, Observed his courtship to the common people, How he did seem to dive into their hearts With humble and familiar courtesy, What reverence he did throw away on slaves, Wooing poor craftsmen with the craft of smiles And patient underbearing of his fortune, As'twere to banish their affects with him. Off goes his bonnet to an oysterwench. A brace of draymen bid God speed him well And had the tribute of his supple knee, With 'Thanks, my countrymen, my loving friends', As were our England in reversion his, And he our subjects' next degree in hope. (1.4.23-36)

This "bending of the aristocratic body towards the common multitude" (Bate 20) is Shakespeare's invention, which can be read as a hint at his intention to make his audience access associations with Essex. 
By highlighting the phenomenon of popularity and dramatising Bullingbrook's rise to power, Shakespeare turns the theatre into an emergent space for debating the mechanisms of power or the justification of rebellion in the context of current political events; he incites the common people to reflect on, or even participate in, political matters.

The way Bullingbrook's courtship undermines hierarchy and legitimacy reminds spectators of Essex, the popular and powerful favourite of Elizabeth I, who will fall into disgrace in the course of his unsuccessful Irish campaign. While Richard looks down on commoners, Bullingbrook allies himself with them and on re-entering London finds favour with the masses in the street (5.2.12-28). Bullingbrook and Richard are both actors in different ways, with the common people as their theatrical audience. Kings and actors are subject to the same conditions of popularity: they must please audiences and they crave applause. The theatre is thus an apt setting, as it works by the same principles of applause (Doty 205). The theatrical stage and the political stage merge, thus illustrating the theatricality and performativity of power.

Many other scenes in the play trigger associations with contemporary events. Richard can rely on well-meaning and true advisers like John of Gaunt, York and Gloucester in contrast to false flatterers like Bushy, Greene, and Bagot. Gaunt in his famous deathbed oration confronts Richard with his sins: he has indulged in flattery, he has spilled royal blood and leased out England:

A thousand flatterers sit within thy crown Whose compass is no bigger than thy head, And yet encagèd in so small a verge The waste is no whit lesser than thy land. Oh, had thy grandsire with a prophet's eye Seen how his son's son should destroy his sons, From forth thy reach he would have laid thy shame, Deposing thee before thou wert possessed, Which art possessed now to depose thyself. Why cousin, wert thou regent of the world It were a shame to let this land by lease, But for thy world enjoying but this land Is it not more than shame to shame it so? Landlord of England art thou now, not king, Thy state of law is bondslave to the law, And thou - (2.1.100-115)

Much in the same manner, Elizabeth, lacking a male heir like Richard, is surrounded by well-meaning favourites and evil-meaning flatterers, and Essex tries 
to rescue her from such men as Cecil, Ralegh and Cobham. Elizabeth is also accused of spilling royal blood in signing Mary Stuart's death warrant. And she leases out her kingdom when granting lands, monopolies, and special privileges to favourites such as Leicester and Essex. The latter has prospered on a farm of sweet wines whose monopoly he loses on returning from Ireland (Campbell 198-200).

After Gaunt Richard's enemies hold charges against him: Northumberland reproaches him with his flatterers, Ross accuses him of charging the commons with high taxes and Willoughby says:

And daily new exactions are devised,

As blanks, benevolences, and I wot not what. (2.1.249-250)

'Benevolences' is a form of taxation much criticised in the 1590s. Shakespeare took the word from his source, Holinshed's Chronicles, which, however, clarified that this practice only dated from the late $15^{\text {th }}$ century. So Shakespeare must have backdated its introduction to Richard's reign in order to shed light on contemporary events (Bate 19).

The centrality of an Irish military campaign also links history, theatre and politics: even Bullingbrook's banishment at the beginning of Richard II might remind spectators in 1599 of Essex, whose Irish campaign was regarded by some (including himself) as a kind of political banishment from Elizabeth's court.

The wooing for popularity "attracted Essex to the story and established parallels with the present: favourites perverting the monarch, unjust taxation, costly and mistaken Irish policies" (Bate 21). There is evidence that Essex himself had a keen interest in the play (Montrose 72). So we can imagine him sitting in the audience and greatly applauding a performance of Richard II, the 'signature play' of the Essex faction, which "played best to the Essex code" (Bate 16). And it is just this play that was commissioned by Charles Percy and his friends at the Globe on the eve of the Essex rebellion. The players finally yielded to the gentlemen's wishes because they were friends to the earls of Essex and Southampton, both generous benefactors and patrons, and they got extra reward and were thus probably not politically motivated (Montrose 73-75).

The performance played into the hands of the rivalling court faction around Cecil, who claimed that Essex had plotted to become another Henry IV planning to set the crown on his own head. They wanted to tie the performance as closely to Essex as possible and therefore falsely claimed it had been commissioned by Essex's steward Meyrick. Luckily for Shakespeare, John Hayward had written a prose work on Richard II (with a notorious dedication to Essex) that could easily be confounded with Shakespeare's work. So the commissioned performance may have prolonged Hayward's imprisonment in the Tower, he might have taken the 
blame for Shakespeare, who was as little pursued as the Lord Chamberlain's Men at the Globe, who performed before the Queen on the eve of Essex's execution (Bate 22-23), which affirms continued royal favour and also continued royal authority over the public theatre. And the Privy Council might have judged the players' intention by means of audience response, i.e. the failed attempt to raise the subjects in the streets in a way saved them (Montrose 68-70).

Although Shakespeare cannot have intended the deposition scene as an allusion to the Essex rebellion (because it had not yet happened at the time of the play's conception), he must have known that showing on stage the deposition of a legitimate monarch is a delicate issue. ${ }^{2}$ Bate concludes that "Richard II was probably not written as an Essex play, but it was certainly read as one" (23).

Janet Dickinson (66) - in contrast to previous critics and historians - argues that Richard II was not commissioned on account of the deposition scene. Firstly, it is unlikely that Essex wished to imitate the rather unhappy sequel to Richard's death, which tainted Henry's reign. Secondly, an audience of the 1590s was probably well aware of this sequel - both historically and dramatically speaking - i.e. rebellion, political instability and a weak crown. So the play was rather commissioned to stress the connection between Bullingbrook's conviction that Richard had been led astray by evil advisors and Essex's analysis of the situation at Elizabeth's court. In other words, the play provided an illustration of the need to act, i.e. to free the country from evil advisors and restore Essex to royal favour.

From Ralegh's letter to Cecil on 6 July 1597, we know that Essex liked to read contemporary affairs in the light of Richard's history (Bate 16). He saw himself like a Bullingbrook riding through the streets of London being greeted and acclaimed, as in York's description of Shakespeare's play:

... the duke, great Bullingbrook,

Mounted upon a hot and fiery steed

Which his aspiring rider seemed to know,

With slow but stately pace kept on his course,

Whilst all tongues cried 'God save thee, Bullingbrook!'

You would have thought the very windows spake,

So many greedy looks of young and old

Through casements darted their desiring eyes

2 Textual or editorial circumstances (inclusion or omission of the deposition scene in Richard II or the topical lines in the fifth Chorus of Henry $V$, e.g.) together with playhouse influences, a general uncertainty about what was actually performed on stage and a lack of exact composition and performance dates complicate any analysis of topicality. The collaborative nature of early modern drama and the resulting lack of a settled text make it all the more difficult to infer audience reception, but might, on the other hand, indicate that Shakespeare in some cases had to yield to censorship or political pressure. 
Upon his visage, and that all the walls

With painted imagery had said at once

'Jesu preserve thee! Welcome, Bullingbrook!' (5.2.7-17)

York's theatrical metaphor is appropriate in view of Bullingbrook's skilful performativity of the modern ruler. These performative notions of legitimacy are also to be found in Henry $I V$ and Henry $V$ and testify to the modernity of the Henriad, which, according to Jean Howard (153-154), explores - in contrast to the first tetralogy - the theatricality of power and legitimacy and acknowledges the theatre as an active and powerful participant in early modern culture.

\section{HENRY IV}

The historical rebellion of Henry Percy and his son Hotspur against King Henry IV and his son Harry, culminating in the Battle of Shrewsbury in 1403, lies at the core of Shakespeare's play. Contemporary playgoers must have felt reminded of the Northern Rebellion of 1569/70, where Henry Percy's descendant, Thomas Percy, and other Catholics tried to reconvert England into a Catholic country with Mary Stuart as their queen. Shakespeare in a way conceived the Percy rebellion against Henry IV upon the pattern of the Percy rebellion against Elizabeth (Campbell 237).

It seems that Shakespeare does not suggest fixed analogies that run like a common thread through his Henriad. The former Bullingbrook as Henry IV, a king with many problems concerning both his son Harry and the rebels, does not necessarily remind spectators of Essex. This time Shakespeare seems to choose a different strategy: on the one hand, Percy's son Hotspur might suggest parallels to Essex, both on account of his brilliant fighting and - with a different intention - his rebellion against the King / Queen. This association becomes all the more plausible if we consider that it was Charles Percy, another descendant of the Percy family and one of Essex's closest friends, who arranged for Richard II to be performed on the eve of the Essex rebellion. (Campbell 229-231) Essex represents a code of honour and chivalry that early audiences might have felt reminded of when hearing King Henry IV enviously regret that not his own but Percy's son “is the theme of honour's tongue" (1.1.80). Honour justifies Essex's behaviour when seeking a direct way to reach the Queen in the course of his rebellion. Interestingly enough, the same line of argumentation was used both by Percy and his followers in the Northern Rebellion of 1569 and by ancestors of the Percy family who in 1403 explained that "the slanderous reports of their enimies" (Holinshed 23, qtd. in Weil and Weil 30) prevented them from directly approaching the King (Weil and Weil 29-30). 
Henry Percy's younger brother, the Earl of Worcester, asked by the King if he is willing to avoid the battle, justifies their rebellion:

We were the first and dearest of your friends.

...

It was myself, my brother, and his son,

That brought you home, and boldly did outdare

The dangers of the time....

You ...

Forgot your oath to us at Doncaster,

And being fed by us, you used us so

As that ungentle gull the cuckoo's bird

Useth the sparrow - ...

We were enforced for safety's sake to fly

Out of your sight, and raise this present head,

Whereby we stand opposèd, by such means

As you yourself have forged against yourself,

By unkind usage, dangerous countenance,

And violation of all faith and troth

Sworn to us in your younger enterprise. (5.1.33-71)

The Percys had once helped the King seize the crown from Richard, but the King's ingratitude and hostility towards them forced them to act. They were entrusted with the subduing of the Welsh rebellion, but their attempts at making peace with the enemy as little met the King's approval as later Essex's attempt to make peace with the Irish met Elizabeth's approval.

On the other hand, Shakespeare makes use of indirect topical allusions as far as Essex is concerned. Charles Whitney ("Festivity") draws our attention to the Coventry scene, an otherwise inconspicuous scene that focuses on the strand of plot dominated by Falstaff. Here Falstaff, as an infantry captain, leads his recruits, whom he defines as "food for powder" (4.2.54), to the decisive battle of Shrewsbury, where they will find their death. The scene revolves around the problem of recruiting, which Elizabethan audiences were only too familiar with after Essex's sacking of Cadiz in 1596. It contains in a nutshell all the bad living conditions that Elizabethans around 1596 had to cope with - from fear of invasion and domestic unrest to bad harvests, high food prices, poverty, famine, and vagrancy (Whitney, "Festivity" 415-416). The Elizabethan audience in a public playhouse being a mixture of people from all social strata - from the so-called groundlings in the pit to the noblemen in the galleries - it is only natural that such a scene with its serious and festive facets triggers many different blends in diverse groups of playgoers. 
Essex was celebrated as a military hero and reached the peak of his popularity after his victory over Spain at Cadiz. And the noblemen among the audience, who were not directly affected by the war, might have rejoiced in the tavern atmosphere of this scene. But the ordinary men who lived in danger of being recruited for military service - after Cadiz more brutally than ever before - were likely to have felt anger at the abuse of recruitment presented on stage (although the recruits themselves did probably not appear in person). Thus the Coventry scene could "prompt a constructive attitude of dissent because it affirm[ed] a [...] plebeian-centered community that opposes contemporary abuses" (Whitney, "Festivity" 443). Falstaff's main speech (4.2.11-48) addresses the playgoers as if they were companions in the tavern giggling over his clever tricks (Whitney, "Festivity" 422), while they might access different memories of the Cadiz expedition:

If I be not ashamed of my soldiers, I am a soused gurnet. I

have misused the King's press damnably. I have got in exchange of

a hundred-and-fifty soldiers three hundred and odd pounds....(4.2.11-13)

Falstaff's actions of drafting civilians into the army or recruiting prisoners might reflect the early modern abuse of these practices, including emptying the London prisons in 1596 to furnish recruits for the Cadiz expedition (Weil and Weil 166-167).

... Nay, and the villains

march wide betwixt the legs as if they had gyves on, for indeed I had the most of them out of prison.... (4.2.33-35)

While Essex's glorious victory at Cadiz is tainted by the brutal procedures of recruitment, Shakespeare finds a more subtle way to serve his interests and foster his positive reception among his first audiences (Whitney, "Festivity" 431). Probably on political pressure from William Brooke, Lord Cobham, himself Lord Chamberlain and thus patron of Shakespeare's company for a short period between August 1596 and March 1597, he changes the name of Oldcastle into Falstaff (Weil and Weil 5). Interestingly enough, the historical Oldcastle, a close friend of Henry V, was an ancestor of the Cobhams, Essex's rivals at court. He was tried for his Lollard beliefs in 1413, escaped from the Tower, organised a rebellion against Henry V, which failed, and thus sealed his death ("Oldcastle"). Lollards were then absorbed into Protestantism during the English Reformation. Falstaff might have appealed in diverse ways to audience members that adhered to different religious beliefs in an age of religious wars between Catholics and Protestants and between moderate Protestants and radical Puritans. In his biblical allusions, Falstaff mocks his own and other religious pretensions and 
makes people laugh, thus possibly alleviating the sharp edge of the situation. Still, Shakespeare is sailing close "to the high winds of Reformation controversy" (Weil and Weil 35). He satirises Oldcastle the martyr and does not take Falstaff's "amend[ing his] life" (3.3.18) seriously. And he chooses Falstaff / Oldcastle as a companion for Prince Hal, who in his soliloquy reveals his plan of (spiritual) reform and of redeeming the evil times, perhaps meaning Richard's and his own (Weil and Weil 10-11, 35-36):

I'll so offend, to make offence a skill,

Redeeming time when men think least I will. (1.2.176-177)

In a way, Ben Jonson's famous appraisal of Shakespeare being 'not of an age, but for all time' is only half true, because he was also 'of an age', namely the heyday of the Reformation with severe religious conflicts inviting spectators to take sides, e.g. when evaluating Falstaff as a kind of early Protestant martyr or simply as a buffoon providing entertainment (Weil and Weil 29).

Lollard views often coincided with later radical sectarian ones, so that Oldcastle could mean a double embarrassment - in terms of religion and as a rebel against the King - to his descendants, the Cobhams (Weil and Weil 36). Falstaff teases or threatens the Prince: "By the Lord, I'll be a traitor then, when thou art king." (1.2.119)

Shakespeare's satire of Oldcastle in order to make fun of his descendants, who were Essex's enemies, would of course satisfy Essex when watching the performance (Whitney, "Festivity" 433). By presenting the aristocratic Oldcastle as a clown and thus fusing history and comedy, "Shakespeare made his play potentially more subversive" (Weil and Weil 26). Falstaff was an extraordinary figure that has kept fascinating audiences for centuries and must have made a strong impression on contemporary playgoers (Weil and Weil 41). But it is to be assumed that mainly the more sophisticated playgoers lived in this particular blend of political rebellion. For the majority of the early audiences, fascination was perhaps rather due to his clown role offering distraction from the daily routine than to his past religious or political roles with a vague potential for topicality.

\section{HENRY V}

This is Shakespeare's history play focussing on Henry V's war and victory in France during the Hundred Years' War. James Shapiro claims that "in 1599 it was impossible to recall Henry V's celebrated invasion of France without reflecting on the fate of Essex's much anticipated campaign in Ireland" (100), which had in itself something theatrical about it. Essex and his men gathered at Tower Hill on 
27 March 1599 at 2 o'clock, just about the time when performances began at the Globe. The opening Chorus admonishes the audience to

Think when we talk of horses that you see them

Printing their proud hooves i'th'receiving earth. (1.0.26-27)

But the departure for Ireland was undermined by thunderstorm and hail showers - in a way a bad omen for the whole enterprise (Shapiro 116-117).

In CBT terms, popular Henry V comes to life to fight a battle in France sharing properties with popular Essex fighting a battle in Ireland. Shapiro claims that "[c]onquest, national identity, and mixed origins - the obsessive concerns of Elizabethan Irish policy - run deep through Henry the Fifth and sharply distinguish it from previous English accounts of Henry's reign" (112). This means that Shakespeare deliberately adds analogies to the Irish campaign in random allusions to Ireland. But there are also direct references to Essex, for instance, when Gower mentions a soldier with "a beard of the general's cut" (3.7.65). Essex's distinctive square-cut beard triggered this fashion after the Cadiz expedition in 1596 (Gurr, Henry $V$ 145). This allusion creates a blend between Henry V's fictional or theatrical world and the contemporary world of the London playgoers who access memories of Essex's victory at Cadiz. Besides, Henry's mercy at Harfleur (3.4) is not recorded of the historical King, but is rather a reference to Essex's generosity towards the Spanish people in Cadiz (Campbell 287).

The Chorus to Act 2 in an overwhelming patriotic rhetoric presents a nation responding to a call to arms, while in early modern London only few were willing to follow Essex to Ireland. Their only motivation was the money to be made by cheating the army. This pattern of expectation (raised by the Chorus) and disenchantment (in the action to follow) is reflected in the Irish campaign and familiar enough to early modern audiences (Shapiro 106-107).

In a brilliant essay on "The Mathematical Blends of Narrator and Hero in Shakespeare's Henry V”, Amy Cook (348-363) presents CBT as helping audiences and readers to understand how the importance of numbers in the initial Chorus and in Henry's 'band of brothers' speech

We few, we happy few, we band of brothers -

For he today that sheds his blood with me

Shall be my brother; ... (4.3.60-62)

elucidates the eventual consolidation of hierarchical structures. "This wooden O" (1.0.13) is too small for the size of battlefields and therefore the Chorus offers a "crooked figure" (15), a zero, lined up with a one and many zeros, which can actually make a million if located in the right place and proper relation to each 
other. The emergent space constituting a million evokes power, force, and size. The established network about numbers, proportions and divisions and the corresponding power prepare the audience for Henry's 'band of brothers' speech. The relativity of numbers to power is central to the emotional and rhetorical strategy of Henry's victory at Agincourt. By seeing themselves as parts of a whole, the soldiers are motivated to achieve the impossible - despite all numeric evidence. Yet, after the battle and the victory - i.e., after the Moor has done his duty - the traditional hierarchy is re-affirmed: zeros remain zeros (with war veterans like Pistol unrewarded), the focus (and the credit for the victory) is on Henry and the aristocracy. Shakespeare ennobles him with the final victory and the French princess as his spouse. And in the theatre, Henry is perhaps played by the lead actor and star Richard Burbage. Thus the blend of the million at the beginning evokes mental spaces that support ideology and hierarchy - also in the minds of early modern playgoers.

On the other hand, critics have time and again pointed out that Shakespeare is glorifying Essex and his military skills in the character of Henry V. In the months before Essex's return from Ireland, audiences certainly lived in the blend that associated Henry's war in France with Essex's war in Ireland. The Chorus to the final act of the play explicitly invites the audience to shift their attention from the theatrical world of Henry $V$ to the real world of 1599 London to welcome home Essex, the "general of our gracious empress" (5.0.30) Elizabeth. Shakespeare explicitly breaks the theatrical illusion (Shapiro 101) and merges the input spaces of the historical, fictional and theatrical worlds of Henry $\mathrm{V}$ with the political world of Essex, who is expected by the audience to return victoriously from Ireland, but only between March and August 1599, as Essex ingloriously returned in September. So the Chorus seems to have been written only for Essex's time and only during the play's first composition to promote a patriotic reading and to align the audience unanimously with their hero (Gurr, "Introduction" 6-7). But it is also possible that the audience never witnessed a performance with these celebratory lines, which were, of course, deleted in September $1599 .^{3}$

In any case, Henry $V$ is an ambivalent play about war that reflects an Elizabethan audience's dividedness on this issue. The play brilliantly catches this

3 Shapiro (102-103) suggests the possibility of reading the general "bringing rebellion broachèd on his sword" (5.0.32) as a warning that Essex might return to London leading a rebellious army. Essex was still suspected by some of his enemies to pretend to the throne himself, to which he seems to have been entitled via Richard Earl of Cambridge, who figures in the play as a traitor conspiring against King Henry. Shakespeare does probably not deliberately link Essex with the Earl of Cambridge. According to Bevington (20) there is also a vague possibility that Shakespeare is not celebrating Essex in the Chorus, but his successor Charles Blount. 
atmosphere of indulging in martial glory and being weary of military challenges. And Shakespeare - as usual - avoids giving away his political views by inserting a whole range of critical voices and having even Henry hold competing arguments and roles in balance (Shapiro 104-105).

\section{THEATRICALITY AND PERFORMANCE}

According to Heywood's 1612 Apology for Actors (Shakespeare's) history plays have the function to teach moral lessons, obedience to the sovereign and avoidance of rebellion (Montrose 44). But Shakespeare does not really fulfil this task. One of his (and Marlowe's) innovative achievements is the very renunciation of moral advice in contrast to medieval drama. Royal obedience and danger of rebellion are not literally taught but underlie opinion making by the audience in the process of performance.

The social composition at the Globe constitutes an important political factor. Though literacy was comparatively high in urban London, it was by no means a prerequisite for attending performances. Playgoing had a special (aural) appeal to the illiterate as well, who relied on their hearing capacities, but were also attracted by spectacle or by the players with whom most playgoers developed a close familiarity (Gurr, Playgoing 64-65, 126). While many groups of society like women, servants or apprentices were excluded from the Elizabethan political nation, they all - on paying a penny - had access to observing and judging the player-kings, the actors who represented kings, on the stage. The fictional characters in the plays are aware of this. Richard II, e.g., when reflecting on his role muses how ordinary persons are in the position of allowing him a small space where he can be king (Montrose 81):

... and there the antic sits

Scoffing his state and grinning at his pomp,

Allowing him a breath, a little scene

To monarchise, ... (3.2.162-165)

The common man in the audience is allowed to listen to the King's soliloquy, to his inner thoughts and problems, which means that Shakespeare is thus initiating him to state secrets and problems that he is denied in real life (Montrose 84). The soliloquy has firmly established itself by the 1590s as an apt medium for the exploration of the human soul, for meditation, self-presentation, and for the dynamic interaction between actor and spectators. Thus also Henry V, complaining about the burden of royal responsibility, expresses disapproval at being subject to theatrical representation, to the breath of the actor who plays his part: 
We must bear all.

O hard condition, twin-born with greatness,

Subject to the breath of every fool, whose sense

No more can feel but his own wringing (4.1.205-208)

and to the imaginative capacity of the audience, as the introductory Prologue reminds us:

For 'tis your thoughts that now must deck our kings,

Carry them here and there, jumping o'er times,

Turning th'accomplishment of many years

Into an hour-glass. For the which supply

Admit me Chorus to this history,

Who, Prologue-like, your humble patience pray,

Gently to hear, kindly to judge our play. (1.0.28-34)

This introductory Chorus perfectly illustrates the relationship between playwright, actors and audience and literally invokes the mental spaces that are blended. Shakespeare explicitly appeals to "the imaginative authority of the common subject in constituting the political authority of the sovereign" (Montrose 82):

O for a muse of fire, that would ascend

The brightest heaven of invention,

A kingdom for a stage, princes to act,

And monarchs to behold the swelling scene.

Then should the warlike Harry, like himself,

Assume the port of Mars, and at his heels

(Leashed in, like hounds) should famine, sword and fire

Crouch for employment. But pardon, gentles all,

The flat unraisèd spirits, that hath dared,

On this unworthy scaffold, to bring forth

So great an object. Can this cockpit hold

The vasty fields of France? ...

And let us, ciphers to this great account,

On your imaginary forces work.

...

Piece out our imperfections with your thoughts.

Into a thousand parts divide one man,

And make imaginary puissance. (1.0.1-25)

The "warlike Harry, like himself" (5) is an allusion to the actor and to the performative side of the character, who, like Richard II and Henry IV, but also 
like the contemporary Queen, Elizabeth I, was fond of self-performance and self-fashioning. They all shared knowledge about how to perform multiple and important roles demanding that audiences live in several blends. The "port of Mars" (6) might signify the actor's (martial) part (Gurr, Henry V 78); "this unworthy scaffold" (10) together with "this cockpit" (11) convey either an idea of the modest size of the stage and theatre if the play was still performed at the Curtain or are meant satirically if it was one of the first plays to open the newly built Globe (Gurr, "Introduction" 4); "imaginary forces" (18) and "imaginary puissance" (25) both appeal to the spectators' power of imagination. The audience is expected to follow the time travel, the compression of several war years framing Henry's victories from 1415 to 1420 into the few hours of performance ("hour-glass", 31). They should not only see (spectators), but also "hear" (34, audience), i.e. perceive with all their senses, and "judge" (34), which involves a cognitive aspect, including one of drawing analogies to their reality, living in many blends.

The third Prologue ends by encouraging the collective audience to "eke out our performance with your mind" (3.0.35), to evoke and reproduce the victory imaginatively, just as Henry had called upon his soldiers in his 'band of brothers' speech to bring about the victory on the battlefield (Calderwood 178). And early audiences might collectively have hoped for Essex's victory in Ireland while hearing the Chorus speak.

The fictional kings' awareness of being at the mercy of both the common spectator and the actors who play their parts, is in a way mirrored by the real aristocratic protagonists in Elizabethan London. The Queen and Essex shared a predilection for self-presentation, spectacle and ceremony, but they both feared losing control over their (re)presentation by actors on the stage. Elizabeth is known for allegedly saying "we princes ... are set on stages, in the sight and view of all the world" (qtd. in Montrose 80) and Essex is said to have anxiously predicted to the Queen in 1600 that "shortly they will play me in what forms they list upon the stage" (qtd. in Montrose 82). This visibility is in a Foucauldian sense related to power, but also suggests a kind of vulnerability. And the performativity of power, or - in Greenblatt's terms - "the whole theatrical apparatus of royal power" (167), is especially relevant to history plays focussing on English kings, whose creation became culturally and politically important. In his Henriad "Shakespeare dramatized the theatricality of power as a recurrent contest among historical actors to control the personation of the King" (Montrose 93). The legitimacy of King Henry IV and his son, for example, who makes his way from the prodigal prince to the crown, crucially depends on this personation, the characterisation and representation, of the King in the theatre. The King or Queen should not be exposed to ridicule in the theatre, and the royal office should not be damaged. 
Shakespeare might have felt attracted to Henry's reign because it offered much "scope for an imaginative exploration of the interplay between theatricality and political legitimation" (Montrose 98). In other words, a performance in the Elizabethan public theatre invites analogies between the fictional world of the characters and the experiential world of the audience, and the emergent structure of the blend is an individual one in each spectator, which can neither be controlled nor is something that Shakespeare is accountable for. In this sense Shakespeare's Henriad can be perceived as not necessarily promoting Tudor principles like providentialism, but as resonating with potentially subversive vibrations. But the responsibility for this lies solely with the spectator.

In Montrose's (100) terms, the Elizabethan public theatre is a rather unreliable ideological medium in the state service, but it does not work as a means for sedition either, as the case of the failed Essex rebellion suggests. It has a diffuse power that is felt in the process of performance, in which the players and their audience participate in the making of meaning. It does not explicitly advocate political views, but leaves the adoption of such rather implicitly to those who consume the performance.

Apart from the Queen's reliance on pageant and display, her relation to acting in general, and to the public playhouse in particular, is also worth consideration. Her licensing of playing as a profession is an important step that protects the players and satisfies her subjects' needs for entertainment. The public theatre is based on a mixture of aristocratic patronage and market relations. Tensions between Court and City are manifest in the royal taste for theatrical entertainment, whereas $\mathrm{Pu}-$ ritans, and also orthodox Protestant clergymen, seem to associate playing with a Catholic aftertaste seeing analogies between playing and preaching, between spectacle and satanic practices (Montrose 54-65). The theatrical performance has an affective power in the positive sense of entertainment, inspiration, reform, but also in a negative sense, which is visible from the antitheatrical discourse that attacks the public theatre as a corrupt(ing) and immoral institution, a hotbed of vice, mob violence and dangerous ideas (Montrose 45-50).

Elizabethan drama-in-performance seems caught up in an ambivalent mixture between business, entertainment, intellectual stimulation, reflection on political conflicts, moral instruction, and ideological therapy (Montrose 40). Shakespeare's Globe, the most successful prototype of an Elizabethan professional public theatre, is not just a theatre, but a world in itself, as is evident from the theatrum mundi trope. It assembles an audience of thousands of people with a wide social and mental composition, many different levels of awareness as to dramatic illusion and different tastes. The commercial playhouse is "an emergent sociocultural space" (Montrose 20) with a potential to function as a political forum or social platform, but also to satirise contemporary politics. 
The early modern public theatre is "counted on for its political and topical edge" (Shapiro 56).

Yet, given the close link between the Queen and the theatre (company) it is hardly conceivable that Shakespeare in his Henriad could or did afford open offense against the Crown. His acting company enjoyed court favour, even before they - as King's Men - came under the direct patronage of King James I in 1603. Henry Carey, created $1^{\text {st }}$ Baron Hunsdon by Elizabeth I in 1559, enjoyed Elizabeth's particular favour and generosity. His 1570 victory as Lieutenant General of the forces loyal to the Queen in the Northern Rebellion had earned him even more important positions at court, among them as her Lord Chamberlain (Lee). He was thus patron of the arts and the theatre, from 1594 on in particular of Shakespeare's playing company, who performed at public playhouses but also at court.

Besides, Oldcastle's descendant William Brooke was not only married to Frances Newton, a close friend of Elizabeth I, but - as already mentioned - succeeded Henry Hunsdon on the latter's death in 1596 as patron of Shakespeare's company.

\section{CONCLUSION}

The central question as to whether Shakespeare's Henriad is an instrument of contestation or containment can perhaps be solved - in accordance with Louis Montrose (104-105) - through compromise: on a very small formal scale, and only as performed in the public theatre, it could be judged as potentially contesting the dominant ideology. His Henriad might thus not simply be outright political propaganda promoting the Tudor myth and warning against the dangers of civil war and rebellion, as many critics have claimed.

Shakespeare's attitude to his Henriad heroes is as crucial in this context as his relation to Essex, although the latter is next to impossible to characterise. Southampton's association with Essex probably dates from 1591 and was firmly established in 1594 (Hammer 286). Southampton was also a close friend and patron of Shakespeare's, which might indirectly indicate Shakespeare's appreciation of Essex. E.E. Stoll (99) even speaks of the Earl of Essex as Shakespeare's friend. Both Southampton and Essex were avid playgoers and friends of the Lord Chamberlain's Men (while the hostile Cecil faction was oriented towards the Lord Admiral's Men). Both advocated war and hated the Cecil faction. Thus we can forge plausible assumptions that Shakespeare launched a campaign for Essex. According to Bevington (14), Southampton was Catholic, Shakespeare allegedly sympathised with Catholicism. Essex was tolerant in religious matters, but strongly insisting on aggressive war against Catholic Spain, and probably 
a supporter of James VI as successor. Also Essex's popularity with the common man was something he seems to have shared with Shakespeare, who was not born into a noble family and could entertain largely nonelite masses at the Globe theatre.

On the other hand, Bevington considers Shakespeare's allusions to Essex so vague that we can read his admiration of the Earl into his entire dramatic production but that the reverse can also easily be assumed. We know that he had to be careful to avoid censorship and that he escaped conflict with the authorities, when his fellow writers were imprisoned. But it is hardly conceivable that Shakespeare could stay neutral in the political climate of his day, which must have stimulated his imagination. It seems that some middle position is to be assumed. He admired Essex as a man struggling for power but did not approve of his dangerous provocations of Elizabeth towards the end of his career. Perhaps he shared his contemporaries' sympathy with Essex even after the latter's arrest and execution (which happened after the conception of his Henriad), thus bearing witness to an opinion independent of authorities.

All in all, Shakespeare's intentions are as poorly documented as an early modern audience's reception of his (history) plays, but CBT might at least help us to read his Henriad in a new light. In this sense, we can imagine Shakespeare to have intended many diverse emergent structures of historical, fictional, theatrical and contemporary blends among various playgoers. History plays focusing on historical English kings offered the perfect vehicle for opening new and critical ways of discussing the Queen's role and relationship with Essex or the possible contestation of royal authority. Shakespeare deliberately obscured his intentions by allowing many and new associations in different Henriad plays to engage audiences in diverse political discussions about the legitimacy of power and to elicit responses to the pressing problems of his day that seriously concerned them, as they could lead to a much feared civil war - like religious conflict, the continuing war with Spain, the campaign in Ireland, and the unsettled succession; Essex figures prominently in each of these problems. Nonetheless, possible sedition is in the mind of the beholder.

\section{WORKS CITED}

\section{Primary Sources}

Shakespeare, William. King Richard II. 1595. Ed. Andrew Gurr. The New Cambridge Shakespeare. Updated Ed. Cambridge: CUP, 2003.

Shakespeare, William. The First Part of King Henry IV. 1597. Eds. Herbert Weil and Judith Weil. The New Cambridge Shakespeare. Cambridge: CUP, 1997. 
Shakespeare, William. King Henry V. 1599. Ed. Andrew Gurr. The New Cambridge Shakespeare. Updated Ed. Cambridge: CUP, 2005.

\section{Secondary Sources}

Bate, Jonathan. "Was Shakespeare an Essex Man?" Proceedings of the British Academy: 2008 Lectures 162 (2009): 1-28.

Bevington, David. Tudor Drama and Politics: A Critical Approach to Topical Meaning. Cambridge, Mass: Harvard UP, 1968.

Calderwood, James L. Metadrama in Shakespeare's Henriad: Richard II to Henry V. Berkeley: U of California P, 1979.

Campbell, Lily B. Shakespeare's Histories: Mirrors of Elizabethan Policy. London: Methuen, 1964.

Cook, Amy. "Interplay: The Method and Potential of a Cognitive Scientific Approach to Theatre." Performance and Cognition. Theatre Journal 59.4 (2007): 579-594.

Cook, Amy. Shakespearean Neuroplay: Reinvigorating the Study of Dramatic Texts and Performance through Cognitive Science. New York: Palgrave Macmillan, 2010.

Cook, Amy. "The Narrative of Nothing: The Mathematical Blends of Narrator and Hero in Shakespeare's Henry V." Blending and the Study of Narrative: Approaches and Applications. Eds. Ralf Schneider and Marcus Hartner. Berlin: de Gruyter, 2012. 343-365.

Dickinson, Janet. Court Politics and the Earl of Essex, 1589 - 1601. London: Pickering \& Chatto, 2012.

Doty, Jeffrey S. "Shakespeare's Richard II, 'Popularity,' and the Early Modern Public Sphere.” Shakespeare Quarterly 61.2 (2010): 183-205.

Fauconnier, Gilles, and Mark Turner. The Way We Think: Conceptual Blending and the Mind's Hidden Complexities. New York: Basic Books, 2002.

Gajda, Alexandra. The Earl of Essex and Late Elizabethan Political Culture. Oxford: OUP, 2012.

Greenblatt, Stephen. Renaissance Self-Fashioning: From More to Shakespeare. Chicago: The U of Chicago P, 2005.

Gurr, Andrew. Playgoing in Shakespeare's London. Cambridge: CUP, ${ }^{3} 2004$.

Gurr, Andrew. "Introduction." King Henry V. William Shakespeare. The New Cambridge Shakespeare. Updated Ed. Cambridge: CUP, 2005. 1-63.

Hammer, Paul. The Polarisation of Elizabethan Politics: The Political Career of Robert Devereux, $2^{\text {nd }}$ Earl of Essex, 1585-1597. Cambridge: CUP, 1999.

Howard, Jean E. The Stage and Social Struggle in Early Modern England. London: Routledge, 1994. 
Lammers, Lukas. "Eyed awry' - Richard II and the Shapes of History." Shakespeare- Jahrbuch 2011: Shakespeare und die Stadt. Band 147. Ed. Sabine Schülting. Bochum: Kamp, 2011.145-154.

McConachie, Bruce. Engaging Audiences: A Cognitive Approach to Spectating in the Theatre. New York: Palgrave Macmillan, 2008.

McConachie, Bruce and F. Elizabeth Hart, eds. Performance and Cognition: Theatre Studies and the Cognitive Turn. London: Routledge, 2006.

Mettinger, Elke. "Now is this golden crown like a deep well' - Richard II from a Cognitive Point of View." Dramatic Minds: Performance, Cognition, and the Representation of Interiority. Eds. Werner Huber, Elke Mettinger, and Eva Zettelmann. Frankfurt a.M.: Peter Lang, 2015. 83-100.

Montrose, Louis. The Purpose of Playing: Shakespeare and the Cultural Politics of the Elizabethan Theatre. Chicago: The U of Chicago P, 1996.

Moschovakis, Nicholas Rand. "Topicality and Conceptual Blending: Titus Andronicus and the Case of William Hacket." Special Issue: Cognitive Shakespeare: Criticism and Theory in the Age of Neuroscience. College Literature 33.1 (2006): 127-150.

Oatley, Keith. "Simulation of Substance and Shadow: Inner Emotions and Outer Behavior in Shakespeare's Psychology of Character." Special Issue: Cognitive Shakespeare: Criticism and Theory in the Age of Neuroscience. College Literature 33.1 (2006): 15-33.

Pandit, Lalita, and Patrick Colm Hogan. "Introduction: Morsels and Modules: On Embodying Cognition in Shakespeare's Plays.” Special Issue: Cognitive Shakespeare: Criticism and Theory in the Age of Neuroscience. College Literature 33.1 (2006): 1-13.

Rackin, Phyllis. "The Role of the Audience in Shakespeare's Richard II." Shakespeare Quarterly 36.3 (1985): 262-281.

Shapiro, James. 1599: A Year in the Life of William Shakespeare. London: Faber \& Faber, 2005.

Stoll, E.E. "Shakespeare's Presentation of a Contemporary Hero." Shakespeare. Henry V. Ed. Michael Quinn. London: Macmillan, 1969. 95-107.

Weil, Herbert and Judith Weil. "Introduction." The First Part of King Henry IV. William Shakespeare. The New Cambridge Shakespeare. Cambridge: CUP, 1997. 1-60.

Whitney, Charles. "Festivity and Topicality in the Coventry Scene of 1 Henry IV." English Literary Renaissance 24.2 (1994): 410-448.

Whitney, Charles. Early Responses to Renaissance Drama. Cambridge: CUP, 2006. 


\section{Online Sources}

Lee, Sidney. "Henry Carey, Lord Hunsdon (1524?-1596).” 5/9/2016 http://www. luminarium.org/encyclopedia/hunsdon1.htm

“Oldcastle, Sir John." Encyclopaedia Britannica. 5/9/2016 https://www.britannica.com/biography/John-Oldcastle: https:/www.britannica.com/biography/ John-Oldcastle

Elke Mettinger

University of Vienna, Austria elke.mettinger-schartmann@univie.ac.at

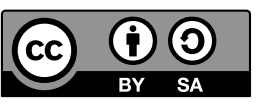

\section{Topičnost in konceptualno mešanje v Shakespearjevi Henriadi- Primer grofa Esseškega}

Cilj tega članka je analizirati topične aluzije na grofa Esseškega v Shakespearjevi Henriadi v smislu konceptualnega mešanja ter možnosti ugotovitve avtorjevih intenc $v$ teh dramah.

Ključne besede: : Shakespeare, Henriada, grof Esseški, konceptualno mešanje, topičnost 